University of Nebraska - Lincoln

DigitalCommons@University of Nebraska - Lincoln

\title{
Short Report: Therapeutic Efficacy of Chloroquine Combined with Primaquine Against Plasmodium falciparum in Northeastern Papua, Indonesia
}

\author{
J. Kevin Baird \\ U.S. Naval Medical Research Unit \# 2, jkevinbaird@yahoo.com \\ Iwa Waidy \\ U.S. Naval Medical Research Unit \# 2 \\ Awalludin Sutanihardja \\ U.S. Naval Medical Research Unit \# 2 \\ Suradi \\ U.S. Naval Medical Research Unit \# 2 \\ Purnomo \\ U.S. Naval Medical Research Unit \# 2 \\ See next page for additional authors
}

Follow this and additional works at: https://digitalcommons.unl.edu/usnavyresearch

Baird, J. Kevin; Waidy, Iwa; Sutanihardja, Awalludin; Suradi; Purnomo; Basri, Hasan; Sekartuti; Ayomi, Ester; Fryauff, David J.; and Hoffman, Stephen L., "Short Report: Therapeutic Efficacy of Chloroquine Combined with Primaquine Against Plasmodium falciparum in Northeastern Papua, Indonesia" (2002). U.S. Navy Research. 55.

https://digitalcommons.unl.edu/usnavyresearch/55

This Article is brought to you for free and open access by the U.S. Department of Defense at DigitalCommons@University of Nebraska - Lincoln. It has been accepted for inclusion in U.S. Navy Research by an authorized administrator of DigitalCommons@University of Nebraska - Lincoln. 


\section{Authors}

J. Kevin Baird, Iwa Waidy, Awalludin Sutanihardja, Suradi, Purnomo, Hasan Basri, Sekartuti, Ester Ayomi, David J. Fryauff, and Stephen L. Hoffman 


\title{
SHORT REPORT: THERAPEUTIC EFFICACY OF CHLOROQUINE COMBINED WITH PRIMAQUINE AGAINST PLASMODIUM FALCIPARUM IN NORTHEASTERN PAPUA, INDONESIA
}

\author{
J. KEVIN BAIRD, IWA WIADY, AWALLUDIN SUTANIHARDJA, SURADI, PURNOMO, HASAN BASRI, SEKARTUTI, \\ ESTER AYOMI, DAVID J. FRYAUFF, AND STEPHEN L. HOFFMAN \\ U.S. Naval Medical Research Unit No. 2, Jakarta, Indonesia National Center for Infectious Diseases Research, Ministry of Health, \\ Jakarta, Indonesia; District Health Services, Jayapura, Papua, Indonesia; Naval Medical Research Center, Silver Spring, Maryland
}

Abstract. Chloroquine combined with primaquine was evaluated for therapy of uncomplicated malaria caused by Plasmodium falciparum in nonimmune Javanese migrants to northeastern Papua, Indonesia. Subjects were randomized to treatment with standard chloroquine therapy $(25 \mathrm{mg} / \mathrm{kg}$ in 3 doses over the course of 48 hours) with $30 \mathrm{mg}$ primaquine administered daily for 28 days $(n=25)$ or a placebo of primaquine $(n=28)$. The 14-day cumulative incidence of therapeutic failure was $56 \%$ with primaquine and $79 \%$ with placebo (odds ratio [OR], $0.35 ; 95 \%$ confidence interval [CI], 0.1-1.3; $P=0.08$ ). Primaquine administered daily created a marginally significant improvement in therapeutic efficacy at day 14 , but not at day $7(20 \%$ versus $36 \%$; OR, $0.2 ; 95 \%$ CI, $0.1-1.8 ; P=0.2)$ or day $28(82 \%$ versus $93 \%$; OR, $0.31 ; 95 \%$ CI, $0.04-2.1 ; P=0.23$ ). This report corroborates studies suggesting that therapeutic doses of primaquine exert no discernible effect on parasitemia by $P$. falciparum.

\section{INTRODUCTION}

Chloroquine and primaquine remain in common use against uncomplicated malaria in the developing world. Chloroquine still constitutes first-line therapy for infection by Plasmodium falciparum for most people exposed to risk in Asia-for example, in India, the Philippines, and Indonesia. Primaquine, which is typically used for the prevention of relapse by Plasmodium vivax (15 mg daily for 14 days), is also widely used in Asia against $P$. falciparum as a single $45-\mathrm{mg}$ gametocytocidal dose. Although therapeutic regimens of primaquine exert curative activity against blood stages of $P$. vivax organisms, ${ }^{1,2}$ most evidence suggests primaquine has no effect on blood stages of $P$. falciparum. ${ }^{3-5}$ This may bear on the finding of apparently distinct mechanisms of resistance to chloroquine by these 2 species. $^{6}$

In July 1992 (Arso VIII) and June 1993 (Arso XI), we enrolled subjects in a randomized, blinded, placebo-controlled trial of a primaquine adjunct to standard chloroquine therapy. The findings with $P$. vivax have been published elsewhere in a report that details the conduct of the studies. ${ }^{2}$ In brief, 53 subjects (nonimmune Javanese migrants) with uncomplicated malaria caused by $P$. falciparum provided informed consent and were randomized to receive standard chloroquine therapy (Resochin; P. T. Bayer Indonesia, Jakarta, Indonesia; provided as uncoated scored tablets; $10+$ $10+5 \mathrm{mg} / \mathrm{kg}$ at 24-hour intervals) with primaquine (generic label, Sanofi-Winthrop, New York, NY, as coated unscored tablets containing $15 \mathrm{mg}$ base, $0.5 \mathrm{mg} / \mathrm{kg}$ daily for 28 days) or a nonidentical placebo (identical to generic primaquine from Kimia Farma, Bandung, as an uncoated, scored tablet containing starch and amylose). Subjects were at least 6 years old and had at least 40 asexual parasites per microliter of blood; in addition, they tested negative for glucose-6-phosphate dehydrogenase deficiency $\left(\mathrm{NADP}^{+}\right.$spot test; Sigma Chemical Co., St. Louis, MO). The mean age of the 53 subjects was 23 years (range, $6-40$ years), and most were men $(n=45)$. The geometric mean density of asexual parasites was $2,744 / \mu \mathrm{L}$. No significant differences in these parameters appeared between the primaquine and placebo groups.

Therapy was directly observed beginning on day 0 of the evaluation and ending with the last dose of primaquine on day
28. Blood films were collected, stained with Giemsa reagents, and read microscopically on days $0,1,2,4,7,11,18,21,25$, and 28 , or at any time a subject complained of illness. Figure 1 illustrates the cumulative incidence of therapeutic failure (persistent or recurrent asexual parasitemia) for both treatment groups estimated by life-table analysis. No significant differences in risk of therapeutic failure occurred between the primaquine and placebo groups. A marginally significant difference appeared only at day 14 (56\% versus $79 \%$; odds ratio, $0.35 ; 95 \%$ confidence interval, $0.4-1.3 ; P=0.08$ ). Daily doses of $0.5 \mathrm{mg} / \mathrm{kg}$ primaquine over the 28 days of follow-up exerted

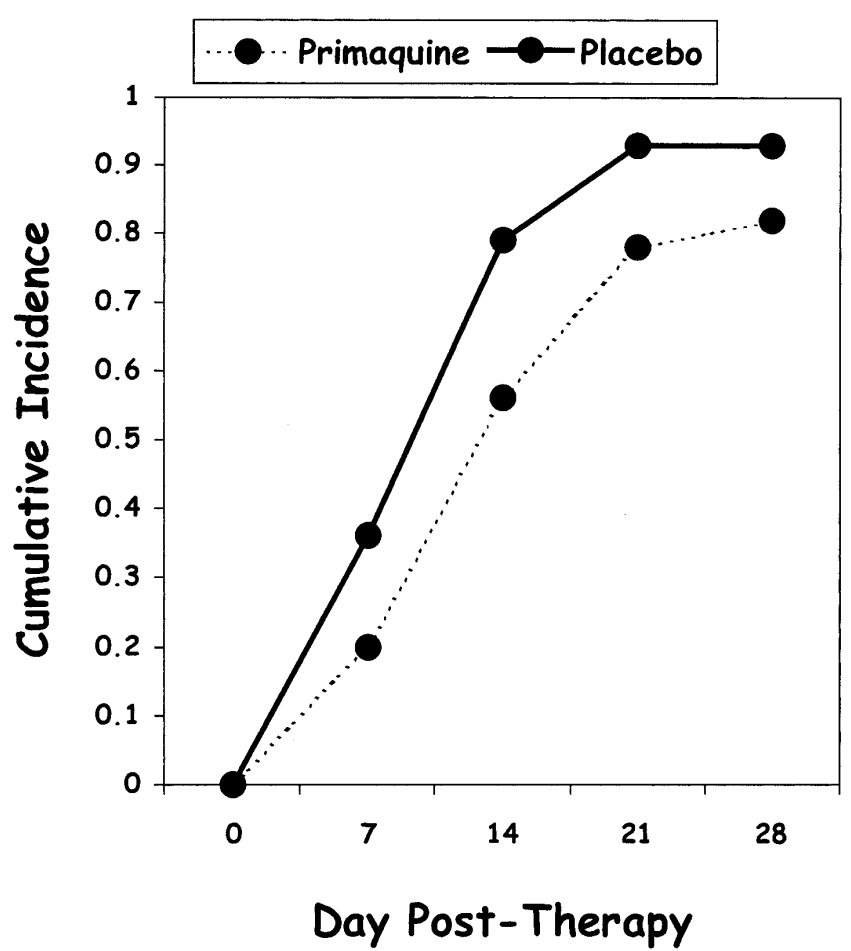

FIGURE 1. Cumulative incidence of recurrent asexual parasitemia by Plasmodium falciparum after chloroquine therapy combined with $30 \mathrm{mg}$ daily primaquine (dashed line) or a placebo (solid line). 
no discernible effect on the clearance and recurrence of asexual parasitemia by $P$. falciparum.

Our findings corroborate others suggesting that therapeutic doses of primaquine exert no effect on asexual parasitemia by $P$. falciparum, despite an apparently profound effect against asexual blood forms of $P$. vivax shown in other studies ${ }^{1}$ and in parallel $^{2}$ with the findings reported here. These findings also corroborate the very high risk of therapeutic failure with chloroquine monotherapy against $P$. falciparum acquired in northeastern Papua, Indonesia. ${ }^{7-9}$

Acknowledgments: The views or opinions herein represent those of the authors and do not purport to represent those of the U.S. Navy or the Department of Defense. This work was supported by the U.S. Department of Defense Global Emerging Infections Surveillance program. The authors gratefully acknowledge the support and direct assistance of the Ministry of Health, Republic of Indonesia, in completing the work described here.

Informed consent: The work described herein was reviewed and approved by Indonesian and American committees for the protection of human subjects of medical research in accordance with U.S. Navy regulations (SECNAVINST 3900.39B). All subjects of this research provided informed consent.

Authors' addresses: J. Kevin Baird, Iwa Wiady, Awalludin Sutanihardja, Purnomo, Suradi, and Hasan Basri, U.S. Naval Medical Research Unit No. 2, American Embassy Jakarta, FPO AP 96520 USA. David J. Fryauff, Naval Medical Research Center, 503 Robert Grant Avenue, Silver Spring, MD 20910-7500. Sekartuti, National Health Research Center, Jalan Percetakan Negara No. 29, Jakarta, Indonesia. Ester Ayomi, District Health Services, PUSKESMAS Jalan Jendral Yani, Jayapura, Papua, Indonesia. Stephen L. Hoffman, Celera Genomics, 45 West Gude Drive, Rockville, MD 20850.

Reprint requests: J. Kevin Baird, Parasitic Diseases Program, U.S. Naval Medical Research Unit No. 2, American Embassy Jakarta, FPO AP 96520-8132, USA, Fax: 62-21-424-4507, E-mail: bairdjk@ namru2.med.navy.mil.

\section{REFERENCES}

1. Pukrittayakamee S, Vanijanonta S, Chantra A, Clemens R, White NJ, 1994. Blood-stage antimalarial efficacy of primaquine in Plasmodium vivax malaria. J Infect Dis 169: 932935.

2. Baird JK, Basri H, Subianto B, Fryauff DJ, McElroy PD, Leksana B, Richie TL, Masbar S, Wignall FS, Hoffman SL, 1995. Treatment of chloroquine-resistant Plasmodium vivax with chloroquine and primaquine or halofantrine. J Infect Dis 171: 1678-1682.

3. Arnold JA, Alving AS, Hockwald RS, Clayman CB, Dern RJ, Beutler E, Flanagan CL, Jeffery GM, 1955. The antimalarial action of primaquine against the blood and tissue stages of falciparum malaria (Panama P-F-6 strain). J Lab Clin Med 46: 391-397.

4. Geary TG, Divo AA, Jensen JB, 1987. Activity of quinoline antimalarials against chloroquine-sensitive and -resistant strains of Plasmodium falciparum in vitro. Trans $R$ Soc Trop Med Hyg 81: 499-503.

5. Basco LK, Bickii J, Ringwald P, 1999. In vitro activity of primaquine against the asexual blood stages of Plasmodium falciparum. Ann Trop Med Parasitol 93: 179-182.

6. Nomura T, Carlton JM, Baird JK, Del Portillo HA, Fryauff DJ, Rathore D, Fidock DA, Su X, Collins WE, McCutchan TF, Wooton JC, Wellems TE, 2001. Evidence for different mechanisms of chloroquine resistance in two Plasmodium species that cause human malaria. J Infect Dis 183: 1653-1661.

7. Baird JK, Basri H, Jones TR, Bangs MJ, Ritonga A, 1991. Resistance to antimalarials in Northeastern Irian Jaya, Indonesia. Am J Trop Med Hyg 44: 640-644.

8. Baird JK, Wiady I, Fryauff DJ, Sutanihardja MA, Leksana B, Widjaya H, Kysdarmanto, Subianto B, 1997. In vivo resistance to chloroquine by Plasmodium vivax and Plasmodium falciparum at Nabire, Irian Jaya, Indonesia. Am J Trop Med Hyg 56: 627-631.

9. Taylor WR, Widjaja H, Basri H, Richie TL, Ohrt C, Taufik, Tjitra E, Hoffman SL, 2001. An open comparison of chloroquine/ doxycycline, chloroquine alone, and doxycycline alone for the treatment of $P$. falciparum and $P$. vivax in northeastern Irian Jaya, Indonesia. Am J Trop Med Hyg. In press. 